\title{
Relationship between iron deposits and tissue damage in the synovium: an ultrastructural study
}

\author{
C J MORRIS, ${ }^{1}$ D R BLAKE, ${ }^{1}$ A C WAINWRIGHT, ${ }^{1}$ AND M M STEVEN ${ }^{2}$ \\ From the ${ }^{1}$ Department of Rheumatology, The Medical School, Birmingham B15 2TJ; and the ${ }^{2}$ Department of \\ Rheumatology, Royal Infirmary, Glasgow
}

SUMmary A detailed ultrastructural study was made of the synovial iron deposits in cases of haemophilic synovitis (HS), pigmented villonodular synovitis (PVNS), rheumatoid arthritis (RA), osteoarthritis (OA), seronegative inflammatory arthritis (SNA), and in controls, to investigate the relationship between iron deposits and tissue damage. Iron was seen by electron microscopy in about $75 \%$ of synovial lining cells in HS and PVNS but only in about $25 \%$ of synovial cells from cases of RA and SNA. In cases of OA and in controls iron deposits were scarce. The iron was usually deposited within pleomorphic siderosomes and in HS was most common in type A synovial cells. In contrast, deposits in all other cases were more common in type B cells, which were frequently the predominant cell type, and siderosomes were smaller, more homogeneous, and were more common in deeper synovial tissue. Considerable tissue damage was noted in the vicinity of iron rich siderosomes in synovial A cells from cases of HS, but such deposits in B cells in the synovium from the other cases had relatively little effect. We discuss the possibility that such differences directly reflect the differing functions of type A and B synovial cells, and particularly their relative ability to produce metabolically active oxygen metabolites with tissue destructive potential in the presence of iron.

Key words: synovial ultrastructure, haemophilic synovitis, pigmented villonodular synovitis, rheumatoid arthritis, osteoarthritis, free radicals.

Considerable quantities of iron are present in the synovial membrane of patients with rheumatoid arthritis (RA), ${ }^{1-4}$ haemophilic synovitis (HS), ${ }^{5-7}$ and pigmented villonodular synovitis (PVNS). ${ }^{8}{ }^{9}$ In rheumatoid arthritis clinical and biochemical evidence has suggested that such deposits are of considerable importance in determining the chronicity of the inflammatory response. ${ }^{10} 11$ Toxic hydroxyl radicals produced from superoxide and hydrogen peroxide in the presence of iron catalysts ${ }^{12}$ have the ability to attack and destroy cell membranes, DNA, and other cell constituents. ${ }^{13} 14$ Also, both free iron and iron saturated ferritin, the intracellular iron storage protein, are able to stimulate lipid peroxidation ${ }^{5}$ in vitro and hence have the potential to disrupt lysosomal membranes and release tissue destructive hydrolytic enzymes in vivo.

We have therefore made a detailed ultrastructural

Accepted for publication 28 June 1985.

Correspondence to Dr C J Morris, Department of Rheumatology,

The Medical School, Birmingham B15 2TJ. study of synovial tissue from both inflammatory and non-inflammatory joint disease to assess whether there is $(a)$ any morphological evidence of tissue damage in association with iron deposits and $(b)$ any difference in distribution and morphology of iron deposits in inflamed and non-inflamed synovium.

\section{Materials and methods}

Synovial membrane was obtained at synovectomy from four cases of haemophilic synovitis (HS), two cases of pigmented villonodular synovitis (PVNS), and from four cases of osteoarthritis (OA) during hip replacement surgery. Closed needle biopsy specimens ${ }^{16}$ of synovial membrane were obtained from nine patients with seronegative arthropathies (SNA) associated with a clinical diagnosis of Crohn's disease (three cases), Reiter's syndrome (two cases), and single cases of Whipple's disease, Behçet's disease, ankylosing spondylitis, and Wegener's granulomatosis. Needle biopsy speci- 
mens of rheumatoid synovial membrane were also studied from 10 cases of classical disease as defined by the American Rheumatism Association, all being seropositive, with Rose-Waaler titres varying from $1 / 32$ to $1 / 512$. Control synovial tissue was obtained at meniscectomy from six individuals without joint disease.

\section{ELECTRON MICROSCOPY}

Synovial tissue $\left(1 \mathrm{~mm}^{3}\right)$ was fixed in $2 \cdot 5 \%(\mathrm{v} / \mathrm{v})$ glutaraldehyde in $0.1 \mathrm{M}$ cacodylate buffer $(\mathrm{pH} 7.4)$ at $4^{\circ} \mathrm{C}$ as soon as possible after removal from the patient. Postfixation was carried out with $2 \%(\mathrm{w} / \mathrm{v})$ aqueous osmium tetroxide at $4^{\circ} \mathrm{C}$, followed by dehydration in graded alcohols and embedding in Spurr's resin. Ultrathin sections were cut on a Reichert OM-U2 ultramicrotome and viewed in a Siemen's Elmiskop 102 electron microscope after contrast with lead citrate and uranyl acetate. A minimum of 50 synovial lining cells were examined in random sections cut from each biopsy specimen, and the percentage of type A and B cells in which siderosomes were present was noted. Thicker $(0.5$ $\mu \mathrm{m})$ sections were cut and analysed for iron content by electron probe microanalysis in a Jeol JEM 1200-EX electron microscope with computerised analytical facilities, as described previously. ${ }^{7}$ For this study the technique was used qualitatively to confirm the presence of iron in synovial cells. Statistical analysis was carried out by Student's $t$ test.

\section{Results}

SIDEROSOME STRUCTURE

Electron dense deposits shown to be rich in iron by electron microscopic $x$-ray microanalysis were present within lysosomal bodies (siderosomes) in the synovial cells of all the cases studied, but whereas the number of synovial lining cells (Table 1) containing siderosomes varied between 70 and $90 \%$ in cases of HS and PVNS, the percentage of such cells present in RA and SNA was only $15-40 \%$. Iron deposits were scarce in cells from OA and normal synovium $(<10 \%)$. In HS iron deposits were present in synovial lining cells as pleomorphic bodies of varying electron density (Fig. 1) and tended to increase in size and electron density in deeper synovial tissue (Fig. 2). The siderosomes in PVNS were smaller, more homogeneous, and tended to be more common in the deeper synovial lining cells (Fig. 3). They never showed the concentric shell structure typical of synovial siderotic deposits in the deeper synovial lining cells and subsynovial macrophages in HS (Fig. 2). Sidersomes in RA and SNA were very similar in structure and location to those of PVNS, tending to be most commonly found in deeper synovial lining cells (Fig. 4). Iron deposits in $\mathrm{OA}$ and normal tissues though relatively uncommon did not seem to be located in specific areas of the synovial tissue. They were usually discrete and frequently associated with subcellular organelles, particularly mitochondria (Fig. 5).

RELATIONSHIP OF SIDEROSOMES TO CELL STRUCTURE

There was considerable tissue damage in the immediate vicinity of siderosomes in HS, particularly

Table 1 Analysis of total numbers of synovial cells containing deposited iron (total cells), and their $A / B$ cell type expressed as mean percentages \pm standard deviation

\begin{tabular}{llcl}
\hline Disorder & A cells & B cells & Total cells \\
\hline HS & $85 \pm 10^{* *}$ & $15 \pm 10^{* *}$ & $80 \pm 10^{*}$ \\
PVNS & $20 \pm 15$ & $80 \pm 15$ & $75 \pm 5^{*}$ \\
RA & $10 \pm 10$ & $90 \pm 10$ & $30 \pm 10$ \\
SNA & $10 \pm 5$ & $90 \pm 5$ & $25 \pm 10$ \\
OA & - & 100 & $<10$ \\
Control & - & 100 & $<10$
\end{tabular}

HS $\mathrm{A} / \mathrm{B}$ percentages are significantly different $\left({ }^{* *} \mathrm{p}<0.001\right)$ from all other disorders. Total cells containing iron are significantly greater $\left({ }^{*} p<0 \cdot 001\right)$ in HS and PVNS than in other disorders and controls.

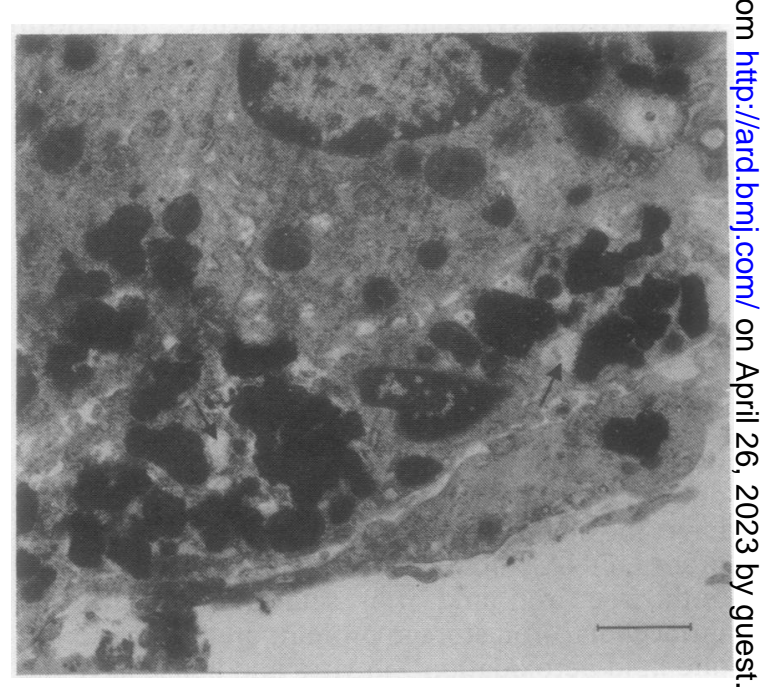

Fig. 1 Electron micrograph of synovial lining cells from a case of haemophilic synovitis. These are collections of electron dense siderosomes in synovial A cells, many of which are surrounded by areas of tissue lysis (arrows) sometimes containing fibrillary material and membranous profiles. Section contrasted with lead citrate/uranyl acetate. Scale line $=2 \mu \mathrm{m}$. 
in the lining cell layer (Fig. 1). Electron dense iron deposits were surrounded by halos of tissue lysis, often associated with mitochondrial destruction and damaged endoplasmic reticulum. This was most obvious for those highly electron dense deposits found to be richest in iron on $x$-ray microanalysis. ${ }^{7}$ The tissue destruction associated with less dense deposits, consisting essentially of ferritin with only small iron loading, was much less obvious. However, in PVNS, RA, and SNA large accumulations of iron had much less effect on the surrounding cell structure (Figs 3 and 4), associated mitochondria and endoplasmic reticulum being well preserved. It was noticeable that in these cases iron was deposited in cells with prominent rough endoplasmic reticulum which were of the synovial B cell type, whereas the deposits in HS were mostly in synovial A cells (Table 1). The small deposits of iron found in the cases of OA and in the normal synovium were also most often associated with apparently normal B cells

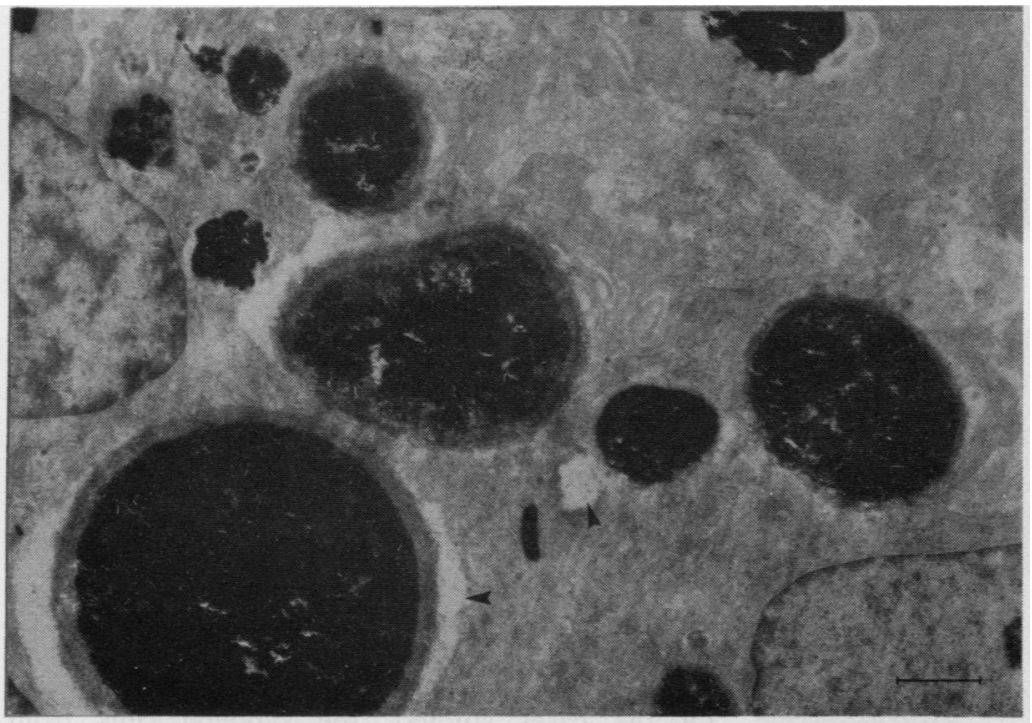

Fig. 2 Electron micrograph of siderosomes in deep synovial macrophages from a case of haemophilic synovitis. The siderosomes have a typical concentric laminated structure and sharply delineated areas of lysis (arrow heads). Lead citrateluranyl acetate. Scale line $=2 \mu \mathrm{m}$.

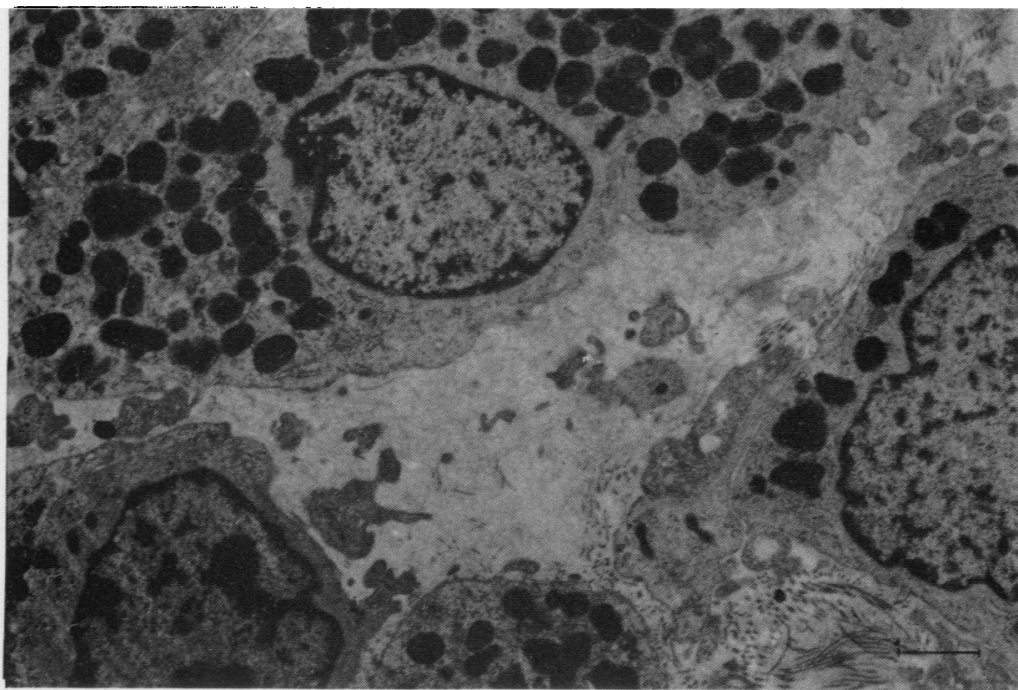

Fig. 3 Electron micrograph of synovial $B$ cells from a case of pigmented villonodular synovitis, containing rounded siderosomes. There is minimal tissue damage adjacent to the iron deposits. Lead citrate/uranyl acetate. Scale line $=2 \mu \mathrm{m}$. 


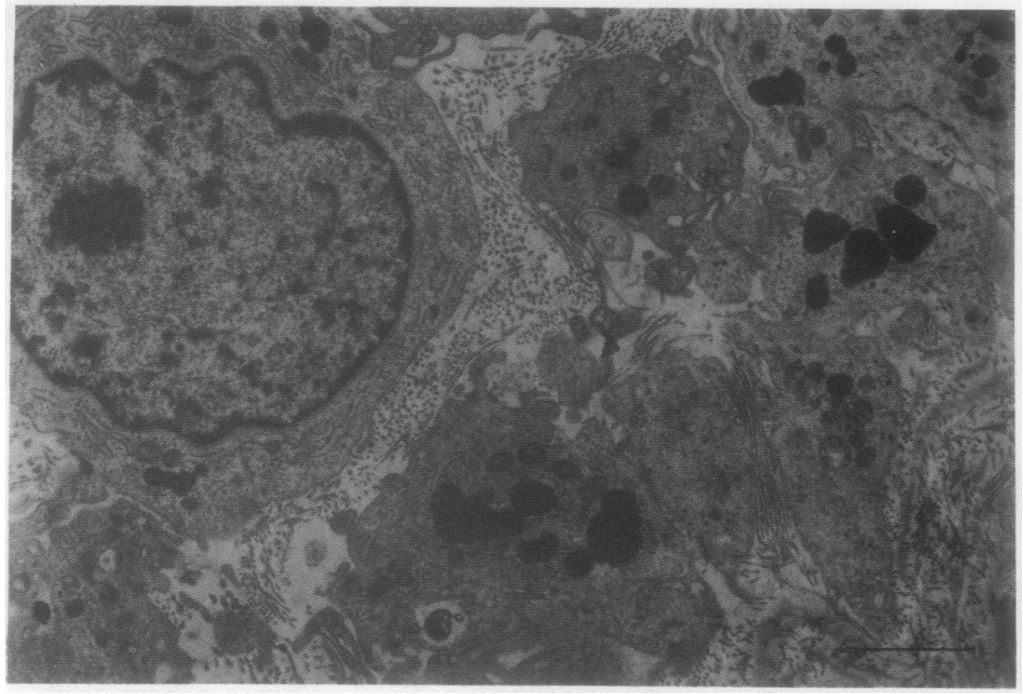

Fig. 4 Electron micrograph of the synovial lining cell layer from $a$ case of rheumatoid arthritis. The rather angular siderosomes in the $B \overrightarrow{\vec{\omega}}$ cells produce little tissue response. Lead citrate/uranyl acetate. Scale line $=2 \mu \mathrm{m}$.

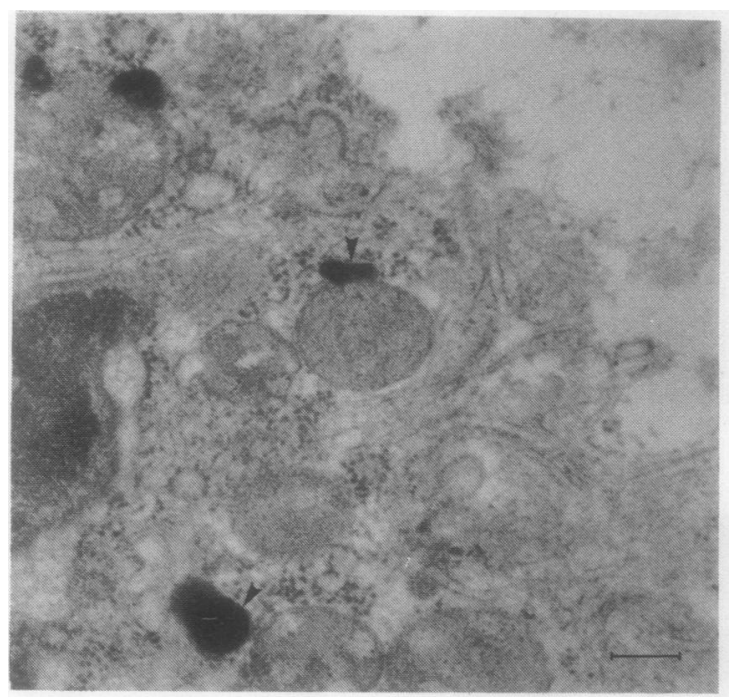

Fig. 5 Electron micrograph of a synovial lining B cell layer from a case of osteoarthritis. Iron deposits (arrow heads) are discrete and are often associated with mitochondria as in this photograph. There is no tissue damage. Lead citrate/uranyl acetate. Scale line $=0 \cdot 2 \mu \mathrm{m}$.

(Fig. 5). It was noticeable that in cases with B cell iron deposition this cell type was the most common in the synovial tissue.

It might be suggested that areas of tissue damage associated with siderosomes are an artefact produced by differential shrinkage during fixation or by tearing during section cutting as a result of differ- ences in hardness between siderosomes and sur $\overrightarrow{-\infty}$ rounding tissues. This is, however, unlikely, sinceo tissue damage is not present in association with alp cell iron deposits and areas of damage contain wels defined membranous structures and filamentous deposits. Section cutting artefacts do occur, buto areas of damage are seen as empty 'holes' in the tissue.

\section{Discussion}

Of the cases studied, the synovial cells from haemophilic synovitis and pigmented villonodularô synovitis were by far the most likely to contain' deposited iron but showed a contrasting tissue reaction to those deposits. Whereas there was aO considerable amount of damage to tissue and $₹$ organelles in the vicinity of siderosomes in음 haemophilic synovitis, no such severe changes were $>$ noted in the synovial cells from cases of PVNS. This is surprising in view of the fact that the iron depositsn in both HS and PVNS may well be derived from the breakdown of erythrocytes phagocytosed from repeated bleeding into the joint space. ${ }^{5-9}$ Also, iron deposits in both diseases are associated with large 0 quantities of ferritin, which is highly iron saturated 0 and would be expected to promote free radical damage $e^{1314}$ and consequent tissue and organelle $\stackrel{?}{?}$ breakdown. There is, however, a marked difference 0 in the type of cells storing iron in the two diseases, the cells being mainly of type $A$ in our cases of HS$\cong$ and of type B in PVNS, as described by several ${ }_{\Omega}^{\mathbb{D}}$ others $^{9}{ }^{17-19}$ and confirmed in the present study. The macrophage-like morphology and phagocytic 
role of type A synovial cells have been well documented, ${ }^{20-25}$ and phagocytic cells such as neutrophils and macrophages have the ability to produce oxygen metabolites ${ }^{26-29}$ with a tissue destructive potential, ${ }^{30}, 31$ a process accelerated by the presence of iron. ${ }^{32} 33$ Fibroblastoid cells do not appear to have this potential, and since synovial B cells are morphologically of this type,$^{34}$ there would be no iron promoted free radical tissue damage in their cytoplasm. There is some evidence that synovial B cells are capable of phagocytosis, but this is by a process of micropinocytosis ${ }^{25}$ and should not produce oxygen radicals. Such a contrasting physicochemical reaction to cytoplasmic iron deposits in type A and B synoviocytes would not only explain the lack of iron related cell organelle damage in cases of PVNS but also similar findings in synovial cells from cases of SNA, RA, and OA where the iron containing cells are also mainly of type $B$. These observations in our cases of RA contradict those made previously. In two light microscopic studies both Ogilvie-Harris and Fornaiser ${ }^{4}$ and Blake et al. ${ }^{11}$ noted that Perls' positive material was present in macrophage-like cells. In the former study no indication was given as to how such cells were defined, though in the latter they stained positively with muramidase (lysosyme) but less strongly with antitrypsin or chymotrypsin. However, Blake et al.$^{11}$ also noted that Perls' positive material and apoferritin did not codistribute well and suggested that rheumatoid synovial macrophages might occasionally fail to generate an appropriate apoferritin response.

The apparent dominance of the type B cell as a storer of iron in many of the diseases studied may therefore reflect either the rapid uptake of iron into apoferritin by type A synoviocytes, with concomitant cell damage and breakdown by processes of free radical damage, or the failure of an apoferritin response, with subsequent precipitation of intracellular proteins by iron, and cell death. This would tend to cause the increase in the $B$ cell population noted in all our cases except HS and by others in RA ${ }^{35} 36$ unless defunct cells were replaced by a rapid proliferative process as seen in the HS synovia. It is interesting that a case of HS with decreased cellularity described by Ghadially ${ }^{5}$ contained mainly iron filled B synovial cells.

Another explanation for our results is that synovial cells may change their function, with a transition from an $A$ to $B$ cell morphology as a result of inflammation, ${ }^{37}$ and this may also be the case during local iron overload. Though A and B cells can be defined as distinct cell types at an electron microscopic level, there is no evidence that they derive from different stem cell populations. It may be that the different morphology merely reflects the different functions being performed at the time of biopsy. ${ }^{38}$ The failure of an apoferritin response or the failure of iron to be incorporated into apoferritin might then be responsible for both a change in morphology and in functional status. As it is the synovial B cells that generate prostaglandin $\mathrm{E}$, with the capacity to cause local bone resorption, this hypothesis would explain both the local erosive damage of PVNS, RA, and SNA and the relative lack of it in HS, and the apparent correlation between the amount of iron in the synovium and the extent of erosive damage. ${ }^{39}$

Our thanks are due to Ciba-Geigy Pharmaceuticals (Horsham UK) for financial support. CJM/DRB are financed by the Arthritis and Rheumatism Council for Research, and the West Midland Regional Health Authority.

\section{References}

1 Muirden K D, Senator G B. Iron in the synovial membrane in rheumatoid arthritis and in other joint diseases. Ann Rheum Dis 1968; 27: 38-48.

2 Goldie I. Iron deposition in original and regenerated synovial tissues after synovectomy in rheumatoid arthritis. Clin Orthop 1970; 68: 316-21.

3 Kumar R, Garg M L. Haemosiderin iron in synovial tissue in rheumatoid and tubercular arthritis-a reassessment of the mechanism of deposition. Indian J Med Res 1974; 62: 1146-51.

4 Ogilvie-Harris D J, Fornaiser V L. Synovial iron deposition in osteoarthritis and rheumatoid arthritis. J Rheumatol 1980; 7: $30-6$.

5 Ghadially F N, Ailsby R L. Yong N K. Ultrastructure of the haemophilic synovial membrane and electron-probe $x$-ray microanalysis of haemosiderin. J Pathol 1976; 120: 201-7.

6 Stein H. Duthie R B. Pathogenesis of chronic haemophilic arthropathy. J Bone Joint Surg 1981; 63B: 601-9.

7 Morris C J, Wainwright A C. Steven M M, Blake D R. The nature of iron deposits in haemophilic synovitis--an immunohistochemical, ultrastructural and $x$-ray microanalytical study. Virchows Arch /Cell Pathol] 1984; 404: 75-85.

8 Docken W P. Pigmented villonodular synovitis: a review with illustrative case reports. Semin Arthritis Rheum 1979: 9: 1-22.

9 Schumacher H R, Lotke P. Athreya B. Rothfuss S. Pigmented villonodular synovitis: light and electron microscopic studies. Semin Arthrits Rheum 1982; 12: 32-43.

10 Blake D R, Hall N D, Bacon P A, Dieppe P A. Halliwell B, Gutteridge J M. The importance of iron in rheumatoid disease. Lancet 1981; ii: $1142-4$.

11 Blake D R, Gallagher P J, Potter A R. Ball M J. Bacon P A. The effect of iron on the progression of rheumatoid disease: a histologic assessment of patients with early rheumatoid synovitis. Arthritis Rheum 1984; 27: 495-501.

12 Halliwell $B$. The biological effects of the superoxide radical and its products. Bull Eur Physiopathol Respir 1981; 17: 2-28.

13 Willson $R$ L. Free radicals and tissue damage: mechanistic evidence from radiation studies. In: Slater T F, ed. Biochemical mechanisms of liver injury. London: Academic Press. 1978: 123-224.

14 Crichton $\mathrm{R} R$. Interreaction between iron metabolism and oxygen activation. In: Oxygen free radicals and tissue damage. Amsterdam: Excerpta Medica, 1979: 57-76. (Ciba Foundation Symposium, No 65.)

15 Gutteridge J M, Halliwell B, Treffry A, Harrison P M. Blake $D$ R. Effect of ferritin containing fractions with different iron loading on lipid peroxidation. Biochem $J$ 1983; 209: 557-60. 
16 Williamson N, Holt J P. A synovial biopsy needle. Lancet 1960; i: 799 .

17 Bierther M, Schluter G. Electronmikroscopische untersuchngen zur Enstehung von Reisenzellen aus Histiozyten bei villonodular synovitis. $Z$ Rheumatol 1973; 32: 272-83.

18 Wyllie J C. The stromal cell reaction of pigmented villonodular synovitis. Arthritis Rheum 1969; 12: 205-14.

19 Reginato A, Martinez V, Schumacher H R, Torres J. Giant cell tumour associated with rheumatoid arthritis. Ann Rheum Dis 1974; 33: 333-41.

20 Ball J, Chapman J A, Muirden K D. The uptake of iron in rabbit synovial tissue following intra-articular injection of iron dextran: a light and electron-microscopical study. J Cell Biol 1964; 22: 351-64.

21 Barland P, Novikoff A B. Hamerman D. Fine structure and cytochemistry of the rheumatoid synovial membrane with special reference to lysosomes. Am J Pathol 1964; 44: 853-66.

22 Cochrane W, Davies D V. Palfrey R J. Absorptive functions of the synovial membrane. Ann Rheum Dis 1965; 24: 2-15.

23 Norton W L, Ziff M. Electron microscopic observations on the rheumatoid synovial membrane. Arthritis Rheum 1966: 9: 589-610.

24 Shannon S L, Graham R C. Protein uptake by synovial cells. I. Ultrastructural study of the fate of intra-articularly injected peroxidase. J Histochem Cytochem 1970; 19: 29-42.

25 Chamberlain M A, Petts V, Gollins E. Transport of intravenously injected ferritin across the guinea-pig synovium. Ann Rheum Dis 1972; 31: 493-9.

26 Babior B M, Kipnes R S. Curneutte J T. The production by leukocytes of superoxide. a potential bactericidal agent. J Clin Invest 1973; 52: 741-4.

27 Johnston R B, Keele B B. Misra H P, et al. The role of superoxide anion generation in phagocyte bacterial activity.
Studies with normal and chronic granulomatous disease leukocytes. J Clin Invest 1975; 55: 1357-72.

28 Drath D B, Karnovsky M L. Superoxide production by phagocytic leucocytes. J Exp Med 1975; 141: 257-62.

29 Karnovsky M L, Ladzino J K. Biochemical criteria for activated macrophages. J Immunol 1978: 121: 809-13.

$30 \mathrm{McCord} J \mathrm{M}$, Fridovich I. The biology and pathology of oxygen $\frac{5}{7}$ radicals. Ann Intern Med 1978: 89: 122-7.

31 McCord J M, Roy R S. The pathophysiology of superoxide: roles in inflammation and ischaemia. Can J Physiol Pharmacol os 1982; 60: 1346-52.

32 Bennett R M. Williams E D. Lewis S M. Holt P J L. Synovial iron deposition in rheumatoid arthritis. Arthritis Rheum 1973; 16: $298-304$.

33 Halliwell B, Gutteridge J M. Oxygen toxicity, oxygen radicals, बे transition metals and disease. Biochem $J$ 1984; 219: 1-4.

34 Barland P. Novikoff A B. Hamerman D. Electron microscopy A of the human synovial membrane. J Cell Biol 1962;14: 207-20. G

35 Wyllie J C, Haust M D. Moore R H. The fine structure of synovial lining cells in rheumatoid arthritis. Lab Invest 1966; 15: 519-29.

36 Ghadially F N. Roy S. Ultrastructure of the synovial membrane in rheumatoid arthritis. Ann Rheum Dis 1967; 26: 426-43.

37 Hamerman D. Synovial joints. Aspects of structure and function. In: Balazs E S. ed. Chemistry and molecular biology of the intercellular matrix. London: Academic Press, 1970: 1259-72.

38 Ghadially F N. Fine structure of joints: In: Sokoloff L, ed. The $\vec{\bullet}$ joints and synovial fluid. New York: Academic Press, 1978; 1: $105-176$

39 Muirden K D. The anaemia of rheumatoid arthritis: the significance of iron deposits in the synovial membrane. Aust Ann Med 1970: 2: 97-104. 